\title{
Staphylococcus aureus prevalence in the fresh salad and vegetables of the Quetta city
}

\author{
Sundus Saifullah ${ }^{1}$, Ferhat Abbas ${ }^{1}$, Abdul Samad ${ }^{1}$, Muhammad Rizwan ${ }^{2 *}$, \\ Farah Sabeen Bugti ${ }^{2}$, Saima ${ }^{1}$, Roomeela ${ }^{1}$, Mohammad Yousaf ${ }^{1}$, Tworko \\ Mykhaylo ${ }^{3}$ and Abdul Raziq ${ }^{4}$ \\ 1. Center for Advanced studies in Vaccinology and Biotechnology, University of Balochistan-Pakistan \\ 2. Bio Technology \& Molecular Biology, CASVAB, University of Balochistan-Pakistan \\ 3. Department of Microbiology, Virology and Immunology Ternopil State Medical University-Ukraine \\ 4. Department of Statistics, University of Balochistan-Pakistan \\ *Corresponding author's email: khanr6847@gmail.com \\ Citation \\ Sundus Saifullah, Ferhat Abbas, Abdul Samad, Muhammad Rizwan, Farah Sabeen Bugti, Saima, Roomeela, \\ Mohammad Yousaf, Tworko Mykhaylo and Abdul Raziq. Staphylococcus aureus prevalence in the fresh salad and \\ vegetables of the Quetta city. Pure and Applied Biology. Vol. 7, Issue 1, pp255-262. \\ http://dx.doi.org/10.19045/bspab.2018.70031
}

\begin{tabular}{llll}
\hline \hline Received: 28/11/2017 & Revised: 06/02/2018 & Accepted: 09/02/2018 & Online First: 15/02/2018 \\
\hline
\end{tabular}

\section{Abstract}

Staphylococcal aureus (S. aureus) has been reported as the most prevalent bacteria which can cause foodborne disease worldwide. Since fresh salads, vegetables are consumed uncooked and if contaminated with microbial pathogens may lead to severe food borne illness. This study aimed to evaluate the contamination rate of Staphylococcal aureus in fresh ready to eat salad, sold in local markets of Quetta city, Pakistan. Out of 100 samples tested, 54 were found contaminated with $S$. aureus. Out of 54 S. aureus isolates, 32 (59\%) were coagulase positive S. aureus. However, 22 $(40 \%)$ were coagulase negative. Enumeration of coagulase positive S. aureus samples revealed that only10\% ( $\mathrm{n}=3$ ) of the total collected samples were within the level of acceptance $<20 \mathrm{cfu}^{-1}$, while $40 \%(\mathrm{n}=12)$ sample were almost on the threshold of Borderline $\left(20-<10^{-4} \mathrm{cfu} \mathrm{g}^{-1}\right)$. Whereas $50 \%(\mathrm{n}=17)$ samples were at Unacceptable level $\left(>10^{-4} \mathrm{cfu}^{-1}\right)$. Furthermore, higher $S$. aureus contamination of fresh food samples was observed during early summer season.

Keywords: Bacterial count; Biochemical tests; S. aureus; Salad; Vegetables

\section{Introduction}

Staphylococcus aureus is a pathogenic bacterium which causes food borne illness along with several other diseases [1] and has been reported as most prevalent bacteria which cause intoxication and gastroenteritis throughout the world $[2,3]$. Staphylococcus aureus is a gram positive, coccoid belonging to the family Staphylococcaceae [4]. The cells are spherical, often arranged like clusters of grapes $[5,6]$. This organism produces coagulase and catalase. Staphylococci can survive in harsh condition of dryness and are even capable of high concentrate salt tolerance $[7,8]$.

Around 2.41 million foodborne illness per year is recoded in United States which is mainly caused by $S$. aureus and, yearly six 
deaths out of 1000 of patients has been reported [9]. The vehicles which transmit $S$. aureus to food is during food processing by human source and by animals in dairy through mastitis. Human origin strains are main source of Staphylococcus food poisoning (SFPO). Early in 1936, Denison documented Staphylococcus food poisoning outbreaks occurred among the students of high school. Annually in Australia, almost 1300 cases have been reported of food poising by Staphylococcus aureus [10].

The severity of food born infection depends on the quantity of toxins consumed [11]. If the toxins in the body reach to the concentration of $10^{5} \mathrm{CFU} / \mathrm{ml}$ than it may lead to disease [12]. After the ingestion of food the common symptoms appear within 38 hour which lead to the abdominal cramps, nausea, vomiting and diarrhea. These symptoms are approximately for 24- 48 hour $[13,14]$.

There are various virulence factors associated with the pathogenesis of S. aureus strains [15-17]. Some of them are hemolysins, hyaluronidase, lipases and thermo nuclease $[18,19]$, which cause invasion in tissues of the host cell. The main virulence factors are heat-stable enterotoxins (SEs), that cause the infrequent food-poisoning syndrome or foodborne related outbreaks, and also the Toxic shock syndrome toxin one (TSST-1), that weaken the immune system of a host [15, $17,18,20,21]$.

In developing countries, pre- and postharvest processes and provisions contribute highly to contamination of fresh products. For example, in Pakistan, a quarter of fresh products are irrigated with waste water [22]. The occurrence of foodborne related outbreaks by contaminated fresh vegetables has been increased during the last decade [23]. The consumption of green leafy vegetables provides numerous health benefits, and there is a direct relationship between consumption of these vegetables and the reduction of chronic diseases such as hypertension, diabetes, atherosclerosis, and cancer. The lack of thorough cooking in fresh cuisine can result in foodborne diseases if contaminated by pathogens [24].

The vaccine or immunotherapy designed to prevent $S$. aureus diseases have not been approved so far from US-Food and Drug administration (FDA). To avoid foodborne illness while consuming fresh vegetables and salad it's pertinent to pay attention regarding the hygiene of consumed food [25].

\section{Materials and methods Sample collection}

A total 100 samples of fresh ready to eat salads vegetables were collected randomly from different street vendors, during the month of April to August 2017. The collected samples were transported in thermopol box filled with crushed ice to bacteriology laboratory, CASVAB, University of Balochistan for further processing. Samples were processed for bacterial analysis within 1-5 hour of collection.

\section{Isolation of Coagulase Positive $S$. aureus}

For isolation of $S$. aureus from food samples ISO 6888-1:1999 "Microbiology of food and animal feeding stuffs" method was adopted with some modifications. Briefly $10 \mathrm{~g}$ sample was weighed aseptically into stomacher bags with $90 \mathrm{ml}$ MRD (Maximum Recovery Dilution) and homogenized for 2 minutes. Homogenate was serially diluted $10^{-2}, 0.1 \mathrm{ml}$ from each initial suspension and serial dilution was transferred onto Baird-Parker (BP) agar supplemented with egg yolk emulsion and incubated for $24-48 \mathrm{~h}$ at $37{ }^{\circ} \mathrm{C}$.

\section{Bacterial Quantification and enumeration}

To estimate the extent of contamination of fresh salad and vegetables with $S$. aureus was experiment carried out. Typical black-gray $S$. aureus colonies were with clear hallow zone appeared on BPA agar plates were enumerated and calculations were made to estimate the bacterial load on each sample. Further data was also analyzed according to 
season of the year.

\section{Biochemical tests for identification}

of $S$. aureus

The suspected typical colonies from BPA agar were further streaked on Nutrient Agar (NA) and incubated for $24 \mathrm{hrs}$ at $37^{\circ} \mathrm{C}$. The colonies from NA surface were selected to perform Gram`s staining and microscopy. Identification of $S$. aureus isolates were made by series of biochemical tests such as thermonuclease (TNase), glucose, mannitol, salt tolerance, oxidase, MR-VP (VogesProskauer and Methyl Red) and indole test. Biochemically identified $S$. aureus isolates were further tested for coagulase production by performing coagulase tube test by adding colony in rabbit plasma for the observation of

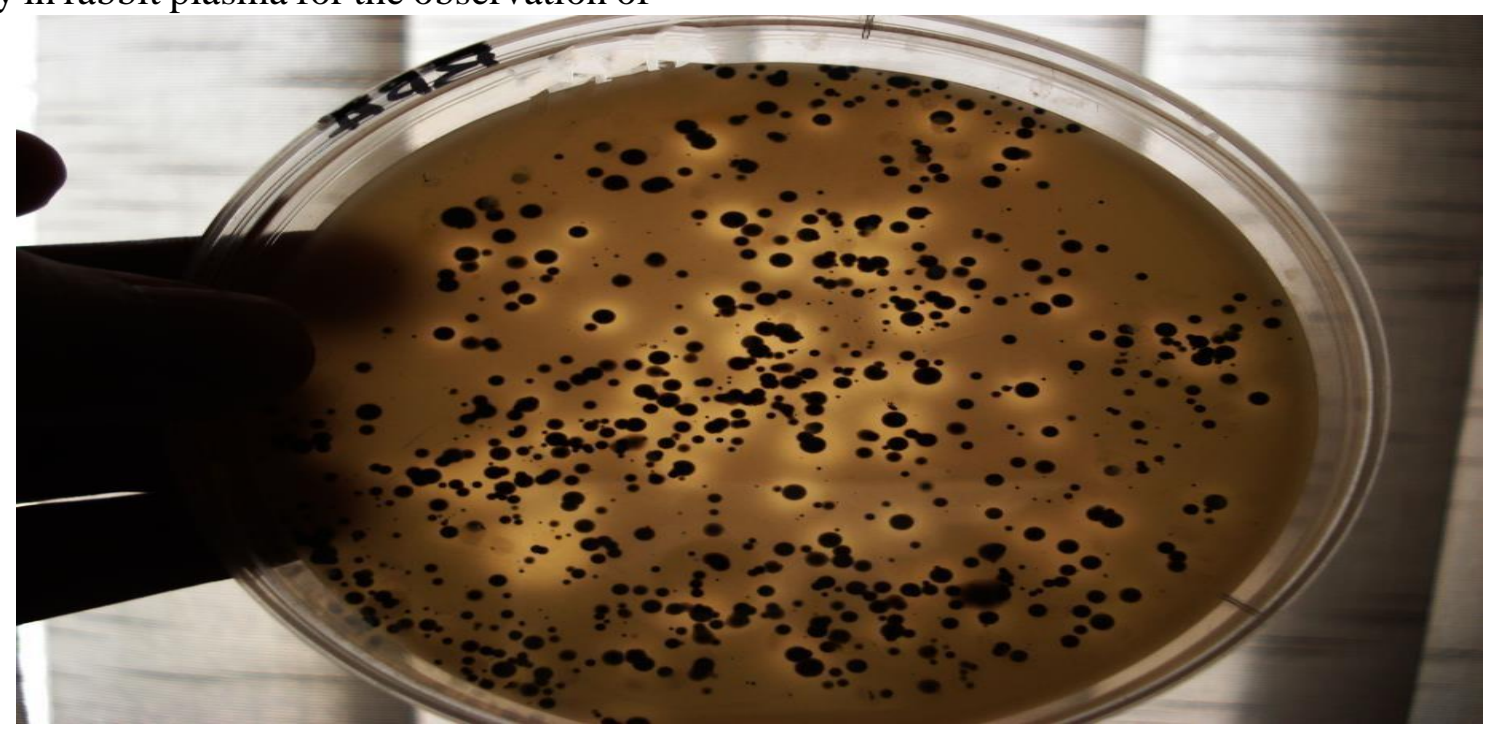

Figure 1. Coagulase positive $S$. aureus in Baird-Parker Agar isolated from salads and vegetables

Table 1. Preliminary biochemical identification of coagulase positive $S$. aureus

\begin{tabular}{|c|c|}
\hline Coagulase & + \\
\hline Catalase & + \\
\hline Oxidase & - \\
\hline MR-VP & + \\
\hline Glucose & + \\
\hline Mannitol & + \\
\hline Salt tolerance & + \\
\hline Indole & - \\
\hline
\end{tabular}

coagulation reaction.

\section{Results}

In this study, Staphylococcus aureus was isolated from 54 out of 100 samples. Growth of staphylococcus aureus on Baired-Parker agar are shown in (Figure 1). The suspected positive $S$. aureus samples were further confirmed by array of biochemical tests like Gram staining cocci positive organism were further confirmed as catalase positive, coagulase positive, negative for oxidase while positive for MR-VP and salt tolerance. While Oxidative fermentation of glucose and mannitol were positive without gas production as shown in (Table1) and (Figure 2). 


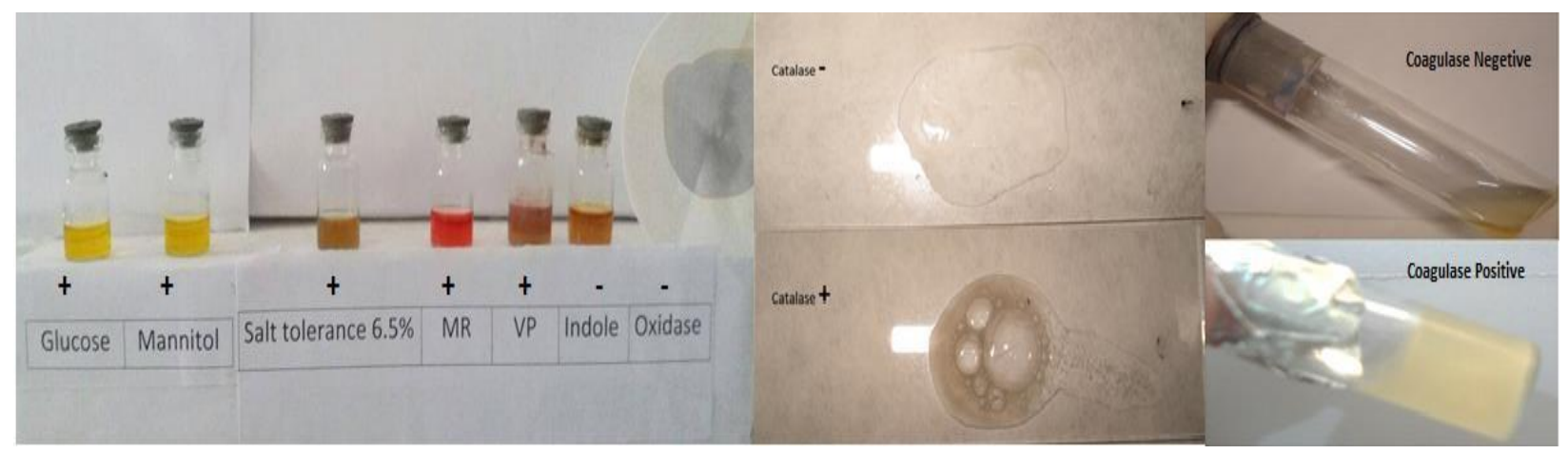

Figure 2. Biochemical identification of coagulase positive S. aureus.

All 32-coagulase positive $S$. aureus were enumerated in cfu/g and converted the value into $\log _{10} \mathrm{cfu} / \mathrm{g}$. The results depicted that only 3 (10\%) samples were within the range of $<20 \mathrm{cfu} \mathrm{g}^{-1}$ which were safe to be consumed, while $12(40 \%)$ samples were almost on the threshold level $\left(20-\leq 10^{-4} \mathrm{cfu} \mathrm{g}^{-1}\right)$ and may not be consumed. Whereas17 (50\%) samples were very high in bacterial count $\left(>10^{4} \mathrm{cfu} \mathrm{g}^{-}\right.$ 1 ) and cannot be consumed (Table 2).

Tube coagulase test was performed on all biochemically identified $S$. aureus. Out of 54 tested samples $32 \quad(59 \%)$ were found coagulase positive and $22(40 \%)$ were found as coagulase negative (Figure 3).

Samples were collected and analyzed during the period of April to August 2017. The results depict that the peak season of $S$. aureus microbial contamination in fresh salads vegetables was May and June. It can be correlated with high yield of local ready to eat salad and vegetables and high temperature during these months of years. Bacterial contamination was decreased with decreasing temperature as shown in (Figure 4).

Table 2. Microbial quantity of coagulase positive $S$. aureus in salads vegetables according to HPA (Health Protection Agency)

\begin{tabular}{|c|c|c|}
\hline Acceptable & $<\mathbf{2 0}$ cfu g-1 & $\mathbf{3}(\mathbf{1 0 \%})$ \\
\hline Borderline & $20-\leq 10^{-4}$ cfu g-1 & $12(40 \%)$ \\
\hline Unacceptable & $>10^{-4}$ cfu g-1 & $17(50 \%)$ \\
\hline
\end{tabular}

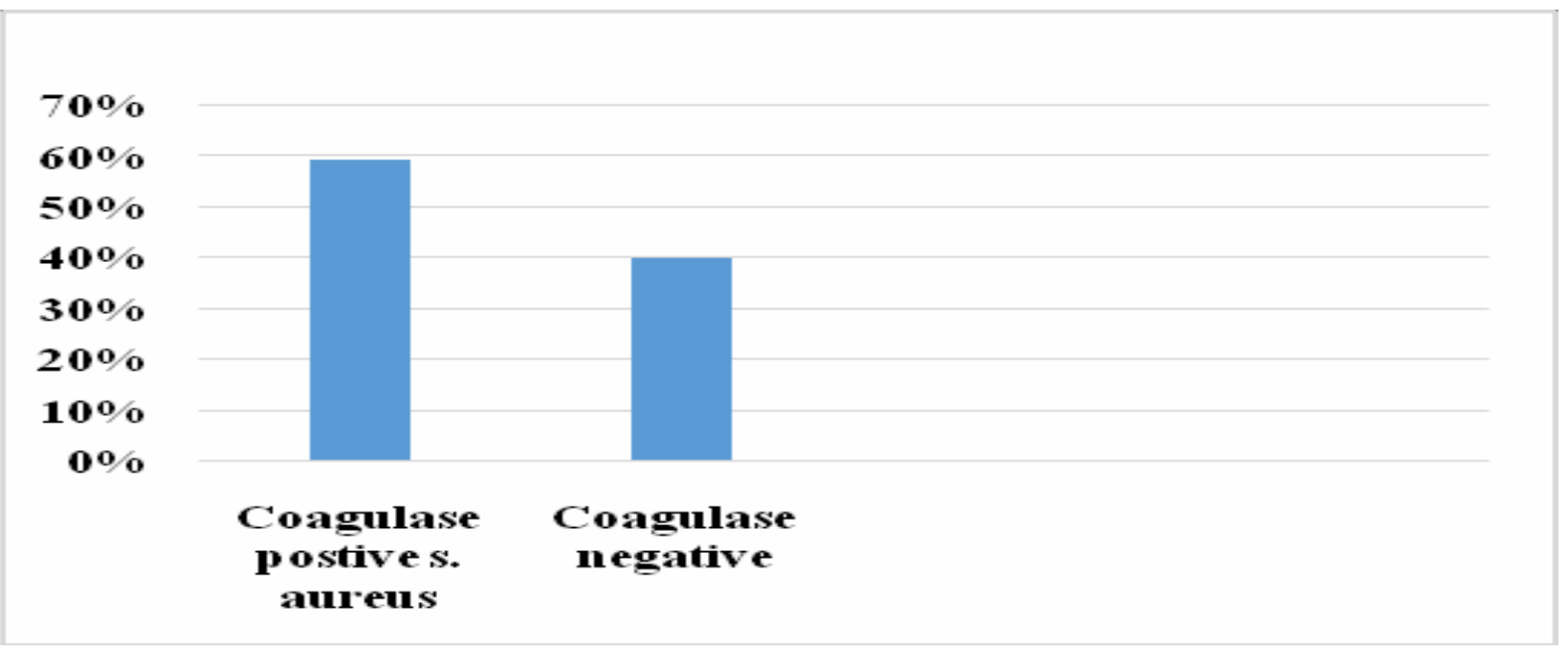

Figure 3. Prevalence of coagulase positive $S$. aureus in salad and vegetables 


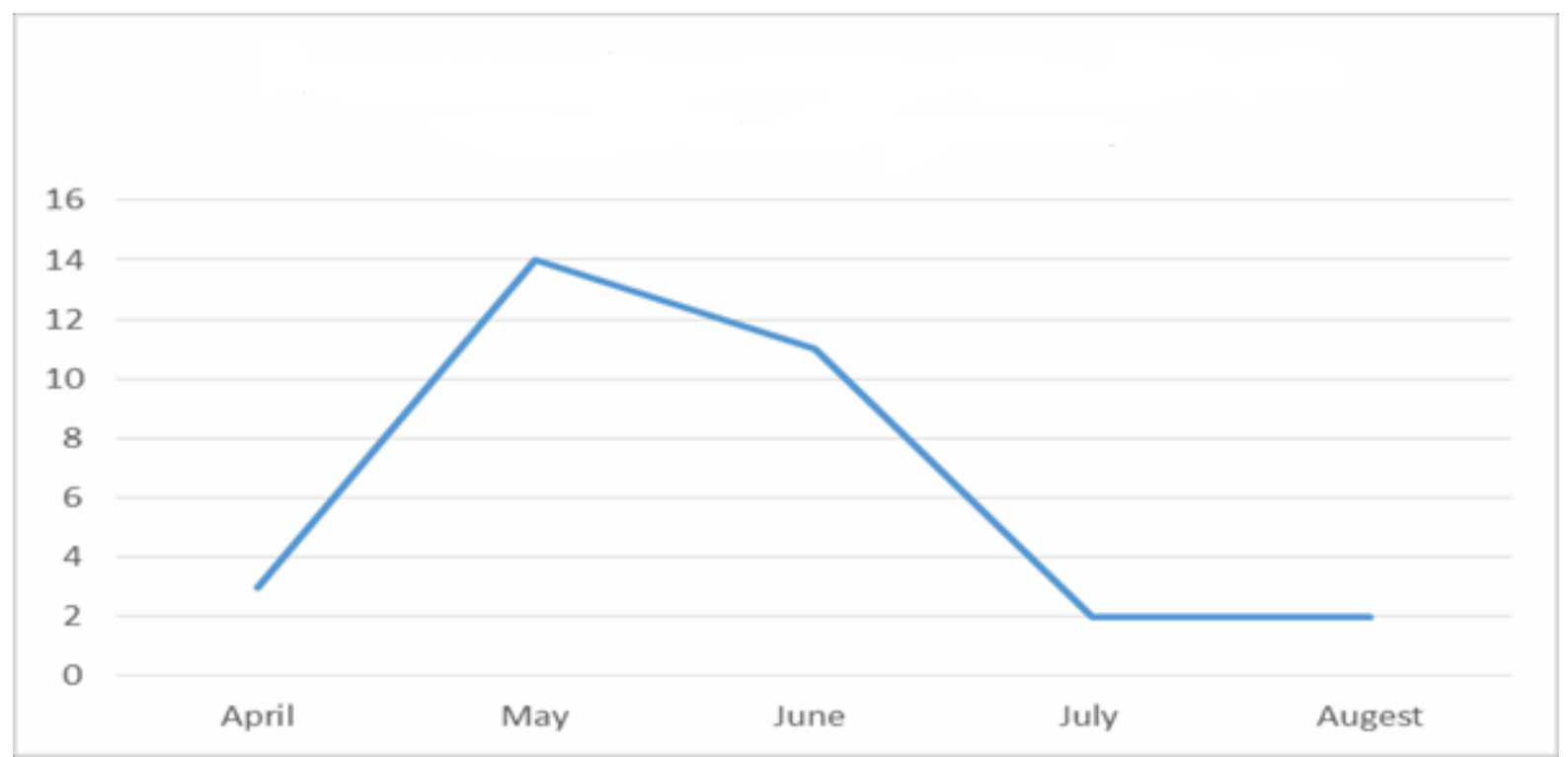

Figure 4. Prevalence of coagulase positive S. aureus during early summer

\section{Discussion}

In recent past the salad and vegetables have become an integral part of daily food. These fresh and uncooked foods may also lead to several foodborne infections if contaminated. Foodborne illnesses pose a great health risk worldwide which can lead to personal distress, economic burden and in certain cases may lead to death [26]. In this study, out of 100 fresh salads/vegetables collected samples tested, 57 samples were found positive for $S$. aureus, importantly 32 of these positive samples were identified as coagulase positive. Several studies in past have reported the fresh food contamination with $S$. aureus and its adverse effect on human health $[27,28]$.

Ideally the food should be free from any pathogen, however, the addible food contaminated with bacterial pathogens under 4 $\log _{10} \mathrm{CFU} / \mathrm{g}$ is still considered as safe however, any food exceeding this threshold should be discarded straightaway [29]. Our study not only detected the $S$. aureus in fresh food but also estimated the load of contamination to get a fair idea about the healthiness of food used by inhabitants of the city. Astonishingly, the $56 \%$ of positive samples harbor more than 4 $\log _{10} \mathrm{CFU} / \mathrm{g}$ bacterial count. The food contaminated with such high number of $S$. aureus is unhealthy and may pose serious health risk to consumers. Even some samples of fresh vegetables and salad were contaminated with $S$. aureus as high as 5 $\log _{10} \mathrm{CFU} / \mathrm{g}$, which is nowhere suitable for human consumption. The coagulase $S$. aureus proliferates in several foods and in suitable condition provide the organism to expend the growth at certain concentration to make food toxic by producing enterotoxins that causes gastroenteritis [30].

The results in this study revealed that the minimum bacterial count was $1.0 \times 10^{-3} \mathrm{cfu} / \mathrm{g}$ and maximum bacterial count was $2.1 \times 10^{-5}$ $\mathrm{cfu} / \mathrm{g}$. The maximum level of bacterial count in fresh food products may be because of irrigation with waste water [31]. We have also observed the same factor as salad and vegetables harvested in Quetta city are irrigated mainly with untreated waste/sewage water and this water serves as a main source of contamination. Similar findings of utilizing waste water for irrigating salads and vegetables is reported in urban region of Quetta city [32]. However, there are also 
several other factors which may contribute to contamination of food items such as poor hygienic practices during collection, storage and transportation. The bacterial contamination of fresh food items which are rich in carbohydrates provide an ideal proliferation condition for microbes [31]. Higher microbial counts have been reported in leafy salads and vegetables $(51.5 \%)$ [33]. Our results are also in agreement with the study recently conducted in Indonesia, which reported is 4 to $6 \log _{10} \mathrm{cfu} / \mathrm{g} \quad S$. aureus contamination [34] .

Although, in this study we have only analyzed the occurrence of $S$. aureus in fresh vegetables and salads samples but still there may be certain other pathogens which may pose serious health risk to human if consumed. Even this study may not be conclusive in term of all bacterial contamination of collected food samples but these results indicate the high $S$. aureus contamination in analyzed samples.

\section{Conclusion}

In developing countries especially those having a very low rain fall, irrigation of salads and vegetables is carried with waste water and this may lead to several foodborne diseases. In Quetta region, due to scarcity of water, farmers cultivate leafy green vegetables and salads in untreated waste water which has significantly high microbial burden and such practices make the food unhealthy.

\section{Authors' contributions}

Conceived and designed the experiments: $F$ Abbas, A Samad \& S Saifullah, Performed the experiments: S Saifullah, Analyzed the data: Saima, Roomeela \& M Yousaf, Contributed materials/ analysis/ tools: M Rizwan, FS Bugti, T Mykhaylo \& A Raziq, Wrote the paper: S Saifullah, Saima \& M Yousaf .

\section{References}

1. Chiang YC, Liao WW, Fan CM, Pai WY, Chiou CS \& Tsen HY (2008). PCR detection of Staphylococcal enterotoxins (SEs) N, O, P, Q, R, U, and survey of SE types in Staphylococcus aureus isolates from food-poisoning cases in Taiwan. Inter J of Food Microbiol 121(1): 66-73.

2. Jablonski LM \& Bohach GA (2001): Staphylococcus aureus. In: Doyle MP, Beuchat L, Montville T (eds): Food Microbiol: Fundamentals and Frontiers 2nd Ed. ASM Press Washington 411- 433.

3. Stewart GC (2005). Staphylococcus aureus. In: Fratamico PM., Bhunia AK., Smith JL. (eds): Foodborne Pathogens. Microbiol and Mol Biol Caister Academic Press Norfolk.

4. Songer JG \& Post KW (2005).Veterinary microbiology. 1st Edn. Bacterial and fungal agents of animal disease. Elsevier Inc 3542.

5. Jay J (2000). Modern Food Microbiology. 6th Edn. Aspen Food Science Text Series 441-456.

6. Shah M (2003). Molecular pathogenesis of S. aureus and other staphylococci. J Appl Bacteriol 59: 207-221.

7. Le Loir Y, Baron F \& Gautier M (2003). Staphylococcus aureus and food poisoning. Genet Mol Res 2(1): 63-76.

8. Aycicek H, Cakiroglu S \& Stevenson TH (2005). Incidence of Staphylococcus aureus in ready- to-eat meals from military cafeterias in Ankara, Turkey. Food control, 16(6): 531-534.

9. Scallae E, Hoekstra RM, Angulo FJ, Tauxe RV, Widdowson MA, Roy SL \& Griffin PM (2011). Foodborne illness acquired in the United States major pathogens. Emerging infectious diseases 17(1): 7.

10. Argudín MÁ, Mendoza MC \& Rodicio MR (2010). Food poisoning and Staphylococcus aureus enterotoxins. Toxins 2(7): 1751-1773.

11. Safety F (2015). Staphylococcus aureus a problem when food is left out too long. Available at: Http://ohioline.Osu.Edu.

12. Evenson ML, Hinds MW, Bernstein RS \& Bergdoll MS (1988). Estimation of human dose of staphylococcal enterotoxin A from a large outbreak of staphylococcal 
food poisoning involving chocolate milk. International J of Food Microbiology, 7(4): 311-316.

13. Gundogan N, Citak S, Yucel N \& Devren A (2005). A note on the incidence and antibiotic resistance of Staphylococcus aureus isolated from meat and chicken samples. Meat Science 69(4): 807-810.

14. Tranter HS (1990). Foodborne staphylococcal illness. The Lancet 336(8722): 1044-1046.

15. Kérouanton A, Hennekinne JA, Letertre C, Petit L, Chesneau O, Brisabois A \& De Buyser ML (2007). Characterization of Staphylococcus aureus strains associated with food poisoning outbreaks in France. Inter $J$ of Food Microbiology, 115(3): 369-375.

16. Normanno La, Salandra G, Dambrosio A, Quaglia NC, Corrente M, Parisi A \& Celano GV (2007). Occurrence, characterization and antimicrobial resistance of enterotoxigenic Staphylococcus aureus isolated from meat and dairy products. Inter $J$ of Food Microbiology 115(3): 290-296.

17. Vancraeynest D, Hermans K \& Haesebrouck F (2007). Prevalence of genes encoding exfoliative toxins, leucotoxins and superantigens among high and low virulence rabbit Staphylococcus aureus strains. Veterinary microbiology 121: 368-372.

18. Sandel MK \& McKillip JL (2004). Virulence and recovery of Staphylococcus aureus relevant to the food industry using improvements on traditional approaches. Food Control 15(1): 5-10.

19. Kuroda M, Nagasaki S, Ito R \& Ohta T (2007). Sesquiterpene farnesol as a competitive inhibitor of lipase activity of Staphylococcus aureus. FEMS Microbiology letters 273(1): 28-34.

20. Tsen HY, Yu GK, Wang KC, Wang SJ, Chang MY \& Lin LY (1998). Comparison of the enterotoxigenic types, toxic shock syndrome toxin I (TSST-1) strains and antibiotic susceptibilities for enterotoxigenic Staphylococcus aureus strains isolated from food and clinical samples. Food Microbiol 15(1): 33-41.

21. Martın MC, González-Hevia MA \& Mendoza MC (2003). Usefulness of a two-step PCR procedure for detection and identification of enterotoxigenic staphylococci of bacterial isolates and food samples. Food Microbiology 20(5): 605-610.

22. Pachepsky Y, Shelton DR, McLain JE, Patel J \& Mandrell RE (2011). 2 Irrigation Waters as a Source of Pathogenic Microorganisms in Produce: A Review. Advances in Agronomy 113(7):73.

23. Mukherjee A, Speh D, Jones AT, Buesing KM \& Diez-Gonzalez F (2006). Longitudinal microbiological survey of fresh produce grown by farmers in the upper Midwest. $J$ of Food Protection 69(8): 1928-1936.

24. López-Gálvez F, Allende A, Truchado P, Martínez-Sánchez A, Tudela JA, Selma MV \& Gil MI (2010). Suitability of aqueous chlorine dioxide versus sodium hypochlorite as an effective sanitizer for preserving quality of fresh-cut lettuce while avoiding by-product formation. Postharvest Biology and Technology 55(1): 53-60.

25. Shinefield H, Black S, Fattom A, Horwith G, Rasgon S, Ordonez J \& Muenz L (2002). Use of a Staphylococcus aureus conjugate vaccine in patients receiving hemodialysis. New England Journal of Medicine 346(7): 491-496.

26. Scharff RL (2012). Economic burden from health losses due to foodborne illness in the United States. $J$ of Food Protection 75(1): 123-131.

27. Viswanathan P \& Kaur R (2001). Prevalence and growth of pathogens on salad vegetables, fruits and sprouts. 
International Journal of Hygiene and Environmental Health 203(3): 205-213.

28. Erkan ME, Vural A \& Oezekinci $T$ (2008). Investigating the presence of Staphylococcus aureus and coagulase negative Staphylococci (CNS) in some leafy green vegetables. Res Biol Sci 3: 930-933.

29. Mohammad B, HabibiNajafi \& $M$ Bahreini (2012). Microbiological Quality of Mixed Fresh-Cut Vegetable Salads and Mixed Ready- to-Eat Fresh Herbs in Mashhad, Iran. International Conference on Nutrition and Food Sciences 39: 6266.

30. Fernández E (2008). Microbiología e inocuidad de losalimentos. Universidad Autónoma de Querétaro. Querétaro, México: Segundaedición.

31. Lynch MF, Tauxe RV \& Hedberg CW
(2009). The growing burden of foodborne outbreaks due to contaminated fresh produce: risks and opportunities. Epidemiology \& Infection 137(3): 307315.

32. Khalil S (2011). Agricultural use of untreated urban wastewater in Pakistan. Asian $J$ of Agriculture and Rural Development 1(1): 21.

33. Hassan SA, Altalhi AD, Gherbawy YA \& El-Deeb BA (2011). Bacterial load of fresh vegetables and their resistance to the currently used antibiotics in Saudi Arabia. Food Borne Pathogens and Disease 8(9): 1011-1018.

34. Hassan ZH \& Purwani EY (2016). Microbiological aspect of fresh produces as retailed and consumed in West Java, Indonesia. Inter Food Research J 23(1): 350-359. 